DOI https://doi.org/10.18551/rjoas.2018-01.24

\title{
ANTIBACTERIAL COMPOUNDS ACTIVITY OF MANGROVE LEAF EXTRACT RHIZOPHORA MUCRONATA ON AEROMONAS HYDROPHYLA
}

\author{
Panjaitan Mikchaell A.P.* \\ Master Program of Aquaculture, Faculty of Fisheries and Marine Sciences, \\ University of Brawijaya, Indonesia \\ Suprajitno Eddy, Hardoko \\ Fishery Technology Study Program, Faculty of Fisheries and Marine Sciences, \\ University of Brawijaya, Indonesia \\ *E-mail: mikchaell@ub.ac.id
}

\begin{abstract}
Pathogenic bacterial infections such as A.hydrophyla in fish cultivation are common problems. A.hydrophyla belongs to a group of bacteria resistant to more than one type of antibiotic. This study aims to determine the antibacterial activity of R.mucronata mangrove leaf extract and to identify potential antibacterial compounds. The research procedure includes extraction, compound refinement, phytochemical test, antibacterial activity test, and KBM-KHM Test. The results show that the antibacterial ability possessed by R.mucronata leaves crude extract increased after the extract was purified utilizing separating funnel. The lowest concentration of methanol fraction extract capable of inhibiting A.hydrophyla (KHM) growth was at $8.25 \pm 0.39 \mathrm{ppm}$, while the lowest concentration of A.hydrophyla was $32.99 \pm 1.56 \mathrm{ppm}$. Bioactive compounds contained in methanol R.mucronata leaves extract are alkaloid compounds, flavonoids, and tannins. Out of the three compounds detected, antibacterial activity is thought to be derived from flavonoid and tannin compounds.
\end{abstract}

\section{KEY WORDS}

Organic solvents, separating funnel, phytochemicals, extract.

Aquaculture is one sector that plays an important role in fulfilling global food needs. Increasing the need for cultivated fish increases aquaculture activities. Fish deaths during cultivation, especially those caused by pathogenic bacterial infections, are still a common problem. Haemorrhagic septicemia, the rot of fan/tail and epizootic ulcerative syndrome are diseases of aquaculture caused by Aeromonas hydrophila.

Treatment of fish that have been infected by bacteria, especially $A$. hydrophila, in cultivation to date still use antibiotics. The use of antibiotics is one-factor triggering bacterial resistance, even against some types of antibiotics. A. hydrophila is one of the bacteria resistant to several types of antibiotics such as penicillin, ampicillin, cephalothin, streptomycin, amoxicillin, oxytetracycline, and streptomycin (Stratev, 2016; Adanir and Turutoglu, 2007).

Utilization of mangroves as drugs raw material has long been developed traditionally by coastal communities (Bandaranayake, 2002). Rhizophora mucronata is one type of mangrove that is known to have biological activity. The bioactive compounds of R.mucronata are derived from secondary metabolite products such as saponins (Mahato et al., 1988), alkaloids (Gurudeeban et al., 2013) and flavonoids (Nurdiani, R, and Awaludin, A, 2012). R. mucronata has antibacterial properties against several Multi Drugs Resistance bacteria (MDR) that infect humans such as Escherichia coli, Staphylococcus aureus, and Klebsiella pneumonia (Joel and Bhimba, 2010).

The purpose of this study was to determine the antibacterial activity of R.mucronata mangrove leaf extract and to identify the class of potential antibacterial compounds. 


\section{MATERIAL AND METHODS OF RESEARCH}

The research material used was R.mucronata leaf. Collected leaves are fresh leaves (still attached to tree trunks) between 10-16 cm. Leaves are then cleaned with aquades to remove dirt and sun-dried. The dried leaves are mashed until the R.mucronata leaf turned to powder.

The method used in this study is laboratory experimental. Obtained data were analyzed utilizing the descriptive method.

Extraction. A total of $1000 \mathrm{~g}$ mangrove leaf powder is macerated utilizing three different solvents based on their polarity levels. The polarity is n-hexane (nonpolar), ethyl acetate (semi-polar) and methanol (polar). It was conducted in order to dissolve all types of bioactive compounds contained in R.mucronata leaves. Leaf powder is macerated with a ratio of 1: 2 (leaf powder: solvent) in stages for $3 \times 24$ hours. The filtrate obtained from the result of maceration was steamed by utilizing rotary evaporator at temperature $\pm 40^{\circ} \mathrm{C}$. The filtrate evaporation process aims to remove the solvent from the extract to obtain a crude extract of R.mucronata leaf (Trianto et al, 2004; Mulyani et al, 2013 and Lim et al, 2017).

Compound Separation. Compound separation used in this study is separation funnel method. This process aims to purify the compounds contained in the extract by attracting other compounds having different polar properties.

A. hydrophila Bacteria Stock Preparation and Suspension. A.hydrophyla were obtained from BBPAP Disease and Pest Laboratory, Jepara. To obtain a stock of pure cultures, A.hydrophila were inoculated into a medium made of Triptic Soy Agar (TSA) by scraping bacterial colonies utilizing ose needles and incubated at $\pm 37^{\circ} \mathrm{C}$ for 24 hours.

Preparation of bacterial suspense was performed by inoculating bacterial colonies in 10 $\mathrm{ml}$ Triptic Soy Broth (TSB) liquid medium and incubated at $\pm 37^{\circ} \mathrm{C}$ for $24 \mathrm{~h}$. Suspense bacteria obtained was put in a vortex process for homogenization prior to use on antibacterial activity test (Sumaryati and Sudiyono, 2015).

Antibacterial Activity Test. The antibacterial activity test aimed to determine the antibacterial potency of R.mucronata leaf extract and extract the separated funnel fraction. The test was performed in agar diffusion method. R.mucronata leaf extract is placed into a petri dish filled with agar medium and suspended A.hydrophyla seeped on disc paper. The antibacterial potency is shown from the clear zone formed around the disc, indicating that the compounds contained in the extract are able to inhibit or kill the growth of A.hydrophyla (Schlegel and Schmidt, 1994). The antibacterial activity test used three different concentrations at $1000 \mathrm{ppm}, 100 \mathrm{ppm}$ and $10 \mathrm{ppm}$ in three repetitions. The incubation period was conducted for $3 \times 24$ hours and the measurement of clear zone diameter was conducted every 24 hours. Drag zone value is the diameter of the clear zone - the diameter of the disc paper.

Minimum Concentration Test (KBM) and Minimum Killing Concentration (KBM). $\mathrm{KHM}$ and $\mathrm{KBM}$ test aims to determine the minimum concentrations that can inhibit and kill A.hydrophyla. Determination of KHM value was conducted utilizing agar diffusion method with test concentrations of 1000ppm, 2000ppm, 3000ppm, 4000ppm, 5000ppm, and $6000 \mathrm{ppm}$. Positive controls used ampicillin and negative controls used DMSO. The test solution was obtained by diluting the extract with DMSO until the desired concentration was obtained. KHM observation was conducted visually by observing the presence or absence of the inhibit zone formed as well as measuring the size of the inhibit zone diameter $(\mathrm{mm})$. The determination of KHM and KBM values was conducted according to Bloomfield (1991). The concentration $\mathrm{KHM}$ and $\mathrm{KBM}$ value were obtained utilizing curve between $\mathrm{X}$-axis In Extract concentrations (In Mo). Y-axis is the quadratic value of resistor area $\left(Z^{2}\right)$.

Qualitative Phytochemical Test. Phytochemical tests were performed to determine the class of compounds contained in the extract. The test was performed according to the procedure described by Setyowati et al (2014), which is an identification of alkaloids. It involved $0.5 \mathrm{~g}$ of extract was added to $1 \mathrm{ml}$ of $\mathrm{HCL} 2 \mathrm{M}$ and $9 \mathrm{ml}$ of aquades, heated for 2 min, cooled and filtered. Reagent dragendorf were added afterward. Should orange to brown color is formed then the extract contains alkaloid compounds. Identification of flavonoids was 
conducted to dissolve the extract in hot methanol. $0.1 \mathrm{~g}$ of $\mathrm{Mg}$ powder and 5 drops of concentrated HCL were added. Should orange color is formed then the extract contains flavonoid compound. Tannin identification was performed by adding $1 \mathrm{ml}$ of $\mathrm{FeCl} 31 \%$ to the extract. The appearance of blue or greenish color indicates the content of tannin compounds. Saponin identification was conducted by dissolving the extract in $10 \mathrm{ml}$ hot water, then shaken for 10 seconds. The content of saponin compound is detected should it formed foam and does not disappear when 1 drop of concentrated HCL is added.

Quantitative Phytochemical Test. Quantification of bioactive compounds in R.mucronata leaf extract utilizing UV-Vis spectrophotometer at $517 \mathrm{~nm}$ wavelength.

\section{RESULTS AND DISCUSSION}

Extraction. The extraction process is carried out by maceration or immersion method to dissolve the bioactive compound contained in R.mucronata leaf. Dried and mashed R.mucronata leaves are weighed to $1000 \mathrm{~g}$ (from $5640 \mathrm{~g}$ of initial weight before dried and mashed) of leaf powder. It is then soaked in an organic solvent with multilevel polarity. Extraction results are exhibited in Table 1.

Table 1 - R.mucronata leaf extraction results with 3 different solvents

\begin{tabular}{ccc}
\hline Solvent & Extract Weight $(\mathrm{g})$ & Extract Immersion (\%) \\
\hline n-Heksan & $7.07 \pm 0.25$ & 0.71 \\
\hline Etil Asetat & $37.51 \pm 0.45$ & 3.803 \\
\hline Methanol & $18.47 \pm 0.71$ & 1.91 \\
\hline
\end{tabular}

Antibacterial Activity Test on R.mucronata Leaf Extract. The antibacterial activity test on the crude extract of R.mucronata leaves to A.hydrophyla aims to determine the antibacterial activity possessed by the three extracts. The soluble compound in the methanol solvent and ethyl acetate exhibited the presence of antibacterial activity with the formation of the inhibitory zone, whereas in the n-hexane solvent there was no inhibition zone. The result of antibacterial activity test on the crude extract of R.mucronata leaf is exhibited in Figure 1.

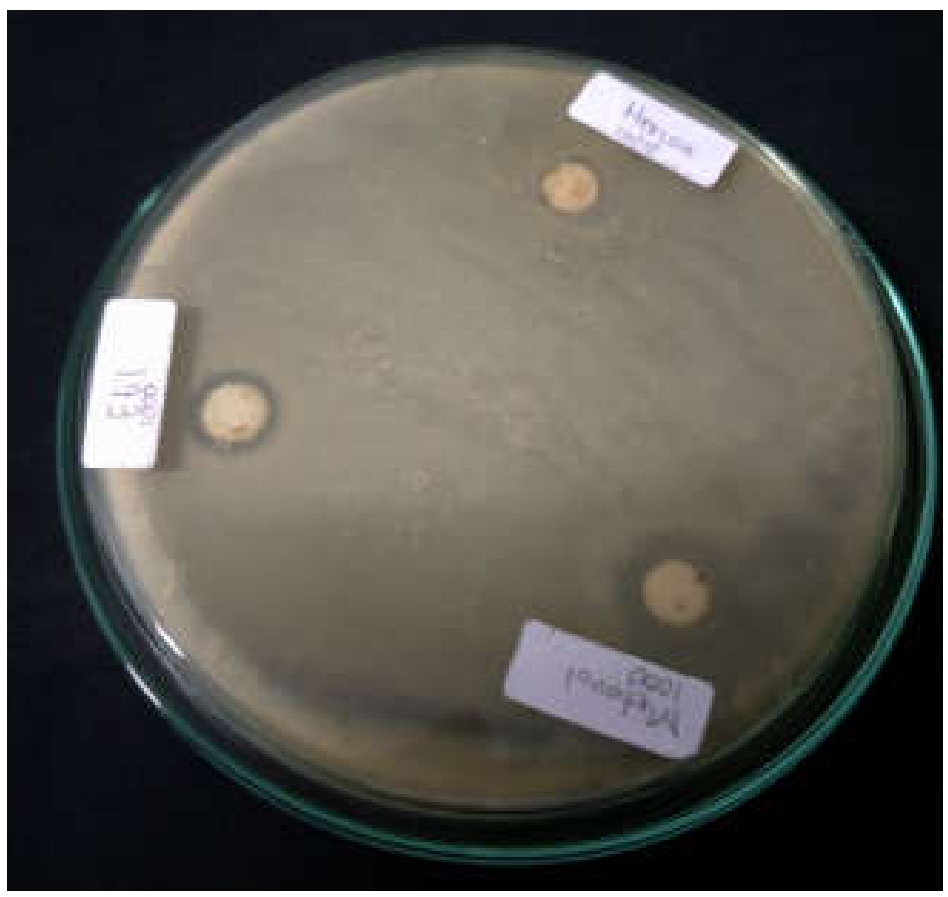

Figure 1 - Results of antibacterial activity test crude extract of R.mucronata leaf

The diameter of the inhibition zone formed from the antibacterial activity test of the crude extract of R.mucronata was $6.5 \pm 0.58 \mathrm{~mm}$ (1000 ppm extract with methanol solvent), 
$2.7 \pm 0.84$ (1000 ppm extract with ethyl acetate solvent). Observation on the amount of drag zone diameter was conducted for $3 \times 24$ hours. Research result exhibited a decrease in drag zone diameter within 48 hours and 72 hours on both extracts and at every concentration. This indicates that the antibacterial activity possessed by R.mucronata leaves is bacteriostatic (Dwijoseputro, 1987, Schlegel and Schmidt, 1994). Antibacterial activity test on a crude extract of R.mucronata leaves exhibited that the extract produced by methanol solvent has the greatest inhibition zone compared to the others. This indicates that the antibacterial compound A.hydrophyla is a polar compound.

Crude extract and methanol solvent were purified utilizing separating funnel. A total of $15 \mathrm{~g}$ of crude extract were separated. Extract fraction is shown in Figure 2.

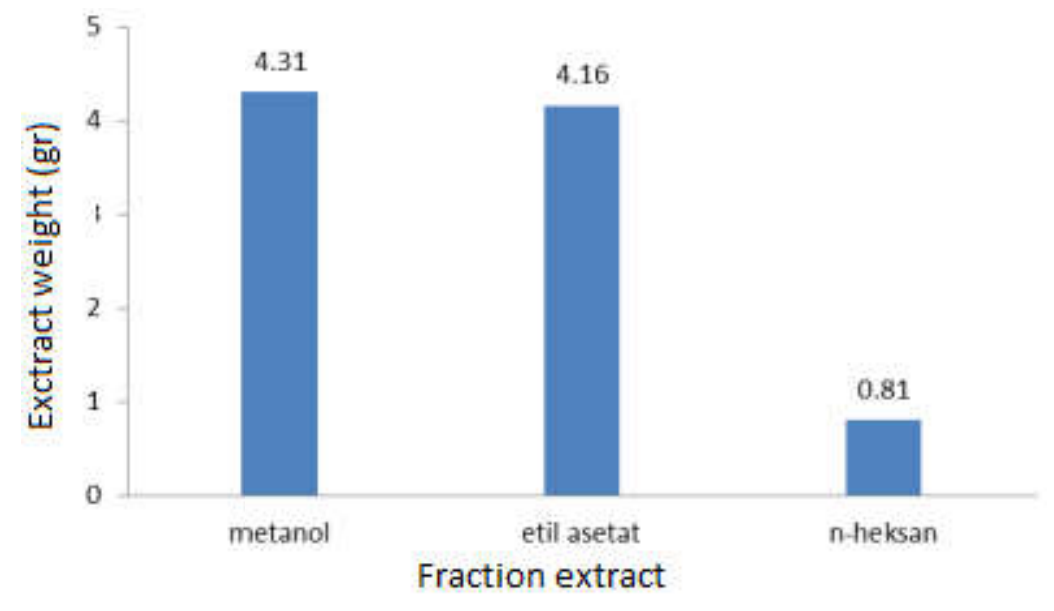

Figure 2 - Graph of weight extract fraction from separated funnel method results

The methanol fraction extract was tested for antibacterial to determine the difference between antibacterial activity possessed and crude methanol extract solvent activity. The results exhibited that the methanol fraction extract had a larger inhibitory zone diameter compared to the crude extract. Nevertheless, both types of extracts possess similar antibacterial bacteriostatic property. Comparison of two extract inhibitory zone diameter at a concentration of $1000 \mathrm{ppm}$ is exhibited in Figure 3. The inhibit zone was formed by methanol fraction extract of $6.9 \mathrm{~mm}$ at a concentration of $1000 \mathrm{ppm}$. It indicates that the R.mucronata leaf possesses moderate resistance to A.hydrophyla according to Greenwood (1995) (Table 2).

Table 2 - Classification of inhibiting responses according to Greenwood (1995)

\begin{tabular}{cc}
\hline Inhibiting diameter $(\mathrm{mm})$ & Inhibiting Power Category \\
\hline$\geq 20$ & Very strong \\
\hline $10-20$ & Strong \\
\hline $5-10$ & Medium \\
\hline$\leq 5$ & Weak \\
\hline
\end{tabular}

In contrast, antibacterial test results of R.mucronata against Staphylococcus aureus performed by Gurudeeban, et al., (2013) exhibited strong antibacterial activity (19.56 \pm 0.19 $\mathrm{mm}$ ). The resistance to $A$. hydrophyla growth is lower compared to S.aureus. It is thought to be caused by both bacteria types. A.hydrophyla is a gram-negative bacteria whereas $S$.aureus is gram-positive. The complexity of the gram-negative structure is higher than that of the simpler gram making the cell wall structure of gram-negative stronger and more difficult to destroy by bioactive compounds (Sari et al 2010). 


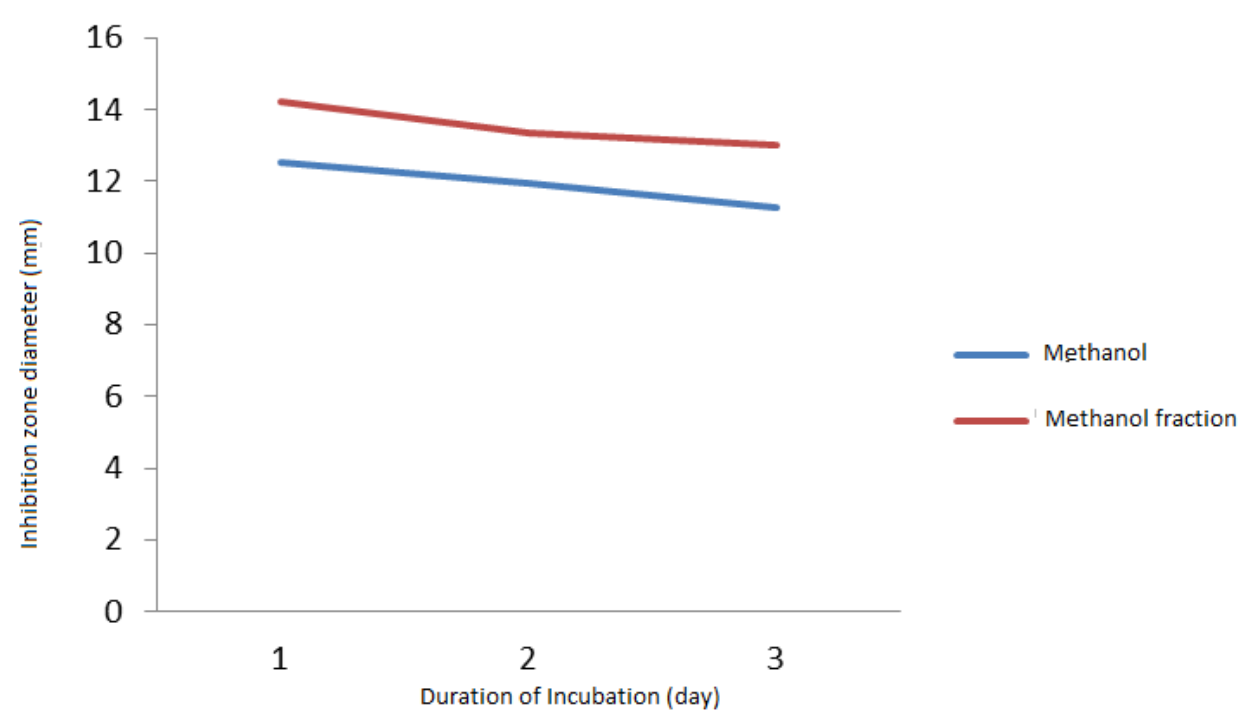

Figure 3 - Graph of inhibition zone diameter comparison between crude extract and methanol fraction extract

KHM and KBM Test. KHM and KBM tests were performed on the extract of the separated methanol fraction. This test aims to determine the lowest concentration capable of inhibiting the growth of A.hydrophyla and kill the bacteria. Methanol fraction extract was dissolved in DMSO, therefore he negative control used is DMSO. Positive control used ampicillin-type antibiotics. The parameters measured in determining KHB and KBM are the resistor zones forming around the disc paper. The antibacterial test results exhibited that in all test concentrations $(6000,5000,4000,3000,2000$, and 1000 ppm) exhibited antibacterial activity.

Based on the measurement of the drag zone formed, it is known that the size of the inhibit zone is directly proportional to the test concentration. The higher the concentration of the inhibitory, the higher the formed drag test zone is (Figure 4). The smaller zone of inhibition was formed at a concentration of $1000 \mathrm{ppm}$. It is suspected due to decreasing bioactive content contained on the paper disc as the concentration decreases. In addition, the small inhibitory zone may also be affected by the presence of bacterial colonies that are resistant to the bioactive compounds contained in the extract (Trianto et al., 2004; Edberg and Berger, 1986).

The existence of the inhibit zone formed indicates that the bioactive compound contained in the extract of the methanol fraction works to inhibit the growth of A.hydrophyla and is not the activity of the test solvent (DMSO). This is exhibited from the absence of inhibition zone in the negative control.

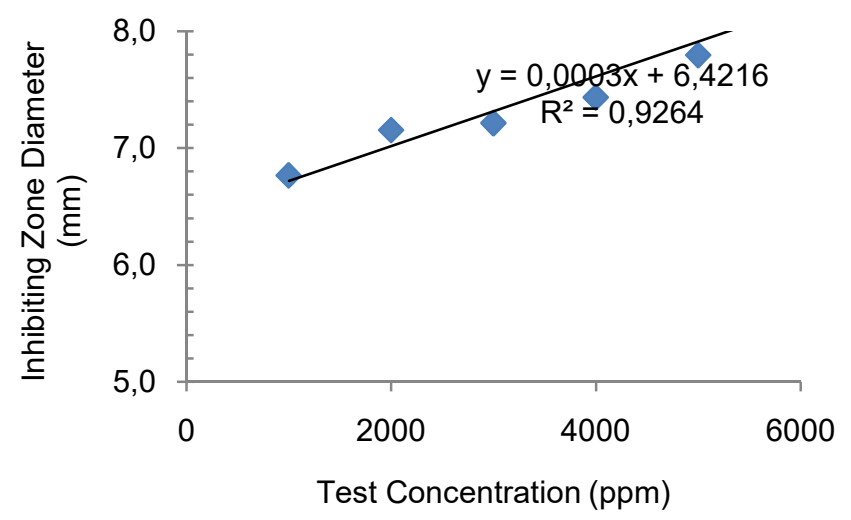

Figure 4 - Graph of inhibiting zone diameter on methanol fraction extract 
The result of diffusion disc test exhibited KHM value of methanol fraction extract at 9.46 $\pm 0.39 \mathrm{ppm}$. This indicates that A.hydrophyla growth can be inhibited by the extract at the lowest concentration of $8.25 \mathrm{ppm}$. While the ability to kill A.hydrophyla from R.mucronata extract is found at the lowest concentration of $37.84 \pm 8.51 \mathrm{ppm}$. The value of KHM and KBM is exhibited in Table 3.

Table 3 - Graph of inhibit zone diameter on methanol fraction extract to A.hydrophyla

\begin{tabular}{ccccccc}
\hline \multirow{2}{*}{ Parameter } & \multicolumn{3}{c}{ Repetition } & \multirow{2}{*}{ Average } & Stdev \\
\cline { 2 - 4 } & 1 & 2 & 3 & & 9.46 & 2.13 \\
\hline KHM & 7.84 & 8.67 & 11.87 & 37.84 & 8.51 \\
\hline KBM & 31.36 & 34.67 & 47.472 & \\
\hline
\end{tabular}

Phytochemical Test. The phytochemical test aims to detect the bioactive compounds contained in the extract of R.mucronata leaf methanol fraction. The test results are exhibited in table 4.

Table 4 - Results of Phytochemical Test

\begin{tabular}{ccc}
\hline Compound & Detection & Concentration (ppm) \\
\hline Alkaloid & + & 135 \\
\hline Flavonoid & + & 1205 \\
\hline Tanin & + & 580 \\
\hline Saponin & - & - \\
\hline
\end{tabular}

+ Exists; - None

The test results exhibited that the bioactive compounds contained in the extract are phenolic compounds such as flavonoids and tannins. The largest concentration of compounds contained in the extract is flavonoids. Flavonoids are polyphenolic compounds produced by plants (Tarahovsky, et al., 2014). These compounds are commonly found in leaves, stems, flowers, and fruits. Flavonoid compounds and their derivatives have the potential to become antibiotics for bacteria resistant to many antibiotics, such as A.hydrophyla. In addition, there are fewer side effects caused by these compounds compared to other natural compounds (Tarahovsky et al., 2014; Cushnie and lamb, 2005). In addition to flavonoids, suspected antibacterial activity in R.mucronata leaf extract also comes from Tannin compounds. According to Hogarth (1999), complex phenolic compounds such as tannins are able to inhibit bacterial activity, therefore, it is often used in the pharmaceutical field. Tannin compounds work as antibacterial to bind and precipitate proteins and promote dehydration of mucosal tissue. In addition, tannins are also able to precipitate other macromolecules such as cellulose and pectin (Manito, 1981 in Trianto et al., 2004).

\section{CONCLUSION}

Research results exhibited that the compound possessing antibacterial ability on R.mucronata leaves dissolved in methanol solvent. Bioactive compounds that potentially possess antibacterial activity were flavonoids and tannins. The lowest concentration of methanol fraction extract capable of inhibiting the growth of A.hydrophyla (KHM) was $9.46 \pm 2.13 \mathrm{ppm}$, while the lowest concentration of $A$. hydrophyla was $37.84 \pm 8.51 \mathrm{ppm}$.

\section{REFERENCES}

1. Adanir, D.O.R and Turutoglu, H. 2007. Isolation and antibiotic susceptibility of aeromonas hydrophila in a carp (cyprinus carpio) hatchery farm. Bull Vet Inst Pulawy 51, 361-364

2. Stratev, D., Odeyemi, O.A. 2016. Antimicrobial resistance of Aeromonas hydrophila isolated from different food sources : A mini review. Journal of infection and public health $9,535-544$ 
3. Bandaranayake, W.M. 2002. Economic, Traditional and Medicinal Uses of Mangroves. Australian Institute of Marine Science. Townsville. $82 \mathrm{p}$

4. Mahato, S.B., Sarkar, S.K. and Poddar, G. 1988. Triterpenoid saponins. Phytochemistry 27: 3037-3067.

5. Gurudeeban, S, Ramanathan, T, and Satyavani, K. 2013. Antimicrobial and Radical Scavenging Effet of Alkaloid Extracts from Rhizophora mucronata.

6. Nurdiani, R, Firdaus, M and Awaludin, A. 2012. Phytochemical Screening and Antibacterial Activity of Metahanol Extract of Mangrove Plant (Rhizophora mucronata) from Porong River Estuary. Journal Basic Science And Technology, 1(2),27-29,2012 ISSN : 2089-8185.

7. Joel, E.L. and Bhimba, V. 2010. Isolation And Characterization Of Secondary Metabolites From Mangrove Plant Rhizophora Mucronata. Asian Pacific Journal of Tropical Medecine. 602-604

8. Trianto, A., Wibowo, E., dan Sapta, R. 2004. Ekstrak Daun Mangrove Aegiceras corniculatum Sebagai Antibakteri Vibrio harveyi dan Vibrio parahaemolyticus. Imu Kelautan. Desember 2004. Vol. 9 (4) : 186 - 189

9. Mulyani, Y., Bachtiar, E., dan Kurnia, M.U. 2013. Peranan senyawa metabolit sekunder tumbuhan mangrove terhadap infeksi bakteri Aeromonas hydrophyla pada ikan mas (Cyprinus carpio L.). Jurnal Akuatika Vol. IV No. 1. ISSN 0853-2523

10. Lim, C.J., Basri, M., Lian, G.C., Omar, D. 2017. Phytoinhibitory activities and extraction optimization of potent invasive plants as eco-friendly weed suppressant against Echinochloa colona (L.) Link. Industrial Crops and Products 100 : 19-34

11. Sumaryati, E. dan Sudiyono. 2015. Kajian Aktivitas Antibakteri Ekstrak Angkak Terhadap Pertumbuhan Bakteri Bacillus cereus dan Bacilus stearothermophillus. Jurnal Teknologi Pangan Vol. 6 No. 1

12. Edberg, C dan Berger, AS. 1983. Antibiotika dan Infeksi. (Terjemahan dr. Chandra Sanusi). Penerbit Buku Kedokteran, EGC. Jakarta. 219 hal

13. Bloomfield, S.F. 1991. Methods for assessing antimicrobial actuvuty. In:Denyer SP, Hugo WB, editors. Mechanisms of action of chemical biocides their study and exploitation. Blackwell Scientific Publication: London

14. Greenwood. 1995. Antibiotics susceptibility (Sensitivity) Test, Antimicrobial and Chemoteraphy. Mc Graw Hill Company, USA

15. Sari, Y.D., Djannah, S.N., Nurani, L.H. 2010. Uji aktivitas antibakteri infusa daun sirsak (Annona muricata L.) secara in vitro terhadap Staphylococcus aureus ATCC 25923 dan Escherichia coli ATCC 35218 serta profil Kromatografi lapis tipisnya. KES MAS Vol. 4 No. $3: 144-239$

16. Tarahovsky, Y., Kim, Y.A., Yagolnik, E.A., Muzafarov, E.N. 2014. Flavonoid membrane interactiona : Involvement of flavonoid-metal complexes in raft signaling. Biochimica et Biophysica Acta (BBA) - Biomembranes Volume 1838: 1235-1246

17. Schlegel, H.G. and Schmidt, K. 1994. Mikrobiologi Umum. Ed. 6. Gadjah Mada University Press, Yogyakarta. 